\title{
THE RELEVANCE OF USING THE MOON'S AGE AS AN ALTERNATIVE IN IMKANUR RUKYAH CRITERIA
}

\author{
Sirna Anwar, Kamaludin Mohd Omar, Mohamad Saupi Che Awang \\ Dept. of Geomatic Engineering, University Technology of Malaysia, Johor Bahru - sirna.anwar@gmail.com, \\ kamaludinomar@utm.my, saupi@utm.my
}

KEYWORDS: Imkanur Rukyah, Hijri Calendar, New Moon Visibility

\begin{abstract}
:
The Imkanur rukyah criteria can be defined as the minimum limit in expecting the new moon's visibility in determining the beginning of Hijri months. It has been used in the development of Hijri calendar in Malaysia since 1992. Based on the criteria, the new moon is considered visible if the altitude at sunset is at least $2^{\circ}$ and the elongation between the moon and the sun is at least $3^{\circ}$, or at moonset, the age of the moon is at least 8 hours. The altitude limit of $2^{\circ}$ and the elongation limit of $3^{\circ}$ indeed were determined according to the data of new moon visibility observed in Indonesia, whereas for the 8-hour moon's age, there is no written rule regarding to it. The use of the moon's age criterion as an alternative to the geometric criteria can lead to confusion if both conditions provide different results. Therefore, this study was performed to assess the relevance of using moon's age as an alternative in Imkanur rukyah criteria used in Malaysia. The study utilised the data of the sun and the moon's positions, the time of sunset, the time of moonset and the time of conjunction (new moon). The data for the sun were calculated based on VSOP87 theory, while for the moon, using ELP2000-82b. Based on the analysis, in determining Hijri dates from 1996 to 2015, there are 22 discrepancies found between the moon's age and the geometric criteria, in which, 5 of them occur in the month of Ramadan, Syawal and Zulhijjah. These conditions show that the moon's age criterion is not always consistent with the geometric criteria. Therefore, the use of moon's age as an alternate criterion in determining the beginning of Hijri month is considered irrelevant and should be further reviewed.
\end{abstract}

\section{INTRODUCTION}

An Islamic calendar is the calendar used for the purpose of Islamic practices and culture. It is also known as the hijri calendar as the calendar dated since the emigration of the Prophet Muhammad pbuh. The calendar is strictly based on lunar calendar/cycle. The Holy Quran states that the Islamic months begin by sighting the new moon, as revealed in Sura Al-Baqarah, verse 185, as follows:

"The month of Ramadhan [is that] in which was revealed the Qur'an, a guidance for the people and clear proofs of guidance and criterion. So whoever sights [the new moon of] the month, let him fast it; and whoever is ill or on a journey then an equal number of other days. Allah intends for you ease and does not intend for you hardship and [wants] for you to complete the period and to glorify Allah for that [to] which He has guided you; and perhaps you will be grateful."

(Sura Al-Baqarah; verse 185)

The determination of the first day of each month of Hijri calendar is very important because it determines the Muslim festival days. Essentially, Muslims need to know when will be the first day of fasting during the month of Ramadan and when will be the Eidul-Fitr celebration. Thus, certain practices have been adopted to determine the condition for new moon to be visible.
Depending on the local appearance of the new moon, then the Hijri calendar varies from one area to another area (Bentchikou et al, 2011). The method of determination also varies depending on the authorities in charge of the country. In Malaysia, the determination of Hijri calendar is made using both the observation and the reckoning methods. Nevertheless, the observation method is used as the main determinant. However, if it is not successful due to factors such as bad weather and cloudy sky, the reckoning method will be used in determining the Hijri calendar.

The methods of observation and reckoning are practised based on the criteria of new moon visibility, which is also known as the Imkanur rukyah criteria. Since 1992, Malaysia has adopted the Imkanur rukyah criteria based on (Azhari, 2012):

(i) The altitude of the moon at sunset, at least $2^{\circ}$ and elongation between the moon and sun, at least $3^{\circ}$, or

(ii) The age of the moon, at least 8 hours when the moon sets.

In preparing the Hijri calendar, if either one, the altitude or the elongation condition is not satisfied, then the moon's age criterion will be used. This is also applicable in the situation where the conditions of the moon's age are not met, but the geometrical parameters (both the altitude and the elongation) are fulfilled. Regarding to this, the use of the moon's age criterion as an alternative may lead to confusion if the result is 
found to contradict the geometric criteria (the altitude and the elongation).

\section{THE IMKANUR RUKYAH CRITERIA}

The use of the new moon visibility criteria has long been practised even before the introduction of the Islamic calendar. The Babylonians used the parameter of intervals time between moonset and sunset, and also the moon's age to predict the appearance of a new moon (Sakirman, 2012). Later, most of the criteria proposed by researchers in the field of modern science and astronomy used the parameters related to the position of the moon and sun, such as the elongation between the moon and the sun, the altitude of the moon at sunset, and the relative azimuth. As per to date, there is not much research done on the moon's age criterion.

\subsection{The Adopted Criteria in Local Region}

The term Imkanur rukyah criteria was first introduced during the Istanbul conference (Muktamar Hilal) held from November $26^{\text {th }}$ till $29^{\text {th }}, 1978$ (Samad et al, 2003). Based on the decision made during the conference, it was agreed that the criteria to be used in determining the initial of Hijri months are:

i. During sunset, moon's altitude at least $5^{\circ}$ and

ii. Elongation of the moon-the sun at least $8^{\circ}$ during sunset

Later, the National Council of Islamic Affairs (Majlis Kebangsaan Hal Ehwal Agama Islam) of Malaysia decided to adopt the Istanbul criteria, with an additional condition; the moon's age more than 8 hours during moonset. On November $4^{\text {th }}, 1991$, Islamic Calendar Technical committee deliberated to use the modified Imkanur rukyah criteria in the determination of Ramadhan and Eidul-Fitr as:

i. During sunset, the moon's altitude of not less than $2^{\circ}$, and the elongation of moon-sun of not less than $3^{\circ}$, or

ii. The age of the moon not less than 8 hours during moonset

On June $1^{\text {st }}$, 1992, the Ministers of Religion for Malaysia, Indonesia, Brunei and Singapore (MABIMS) agreed to adopt these modified criteria in determining the beginning of Ramadan, Syawal and Zulhijjah. Subsequent to the development, since 1996, the Islamic Calendar Technical Committee of Malaysia has included these criteria in determining the beginning of all the hijri months. The conditions of Imkanur rukyah criteria are based on geometry shown in Figure 1. Whereas, the criteria of the moon's age is calculated based on the time period in between the conjunction occurrence (Figure 2) and the time of moonset. Conjunction can be defined as the phenomenon where the moon is at the same ecliptic longitude line with the sun.

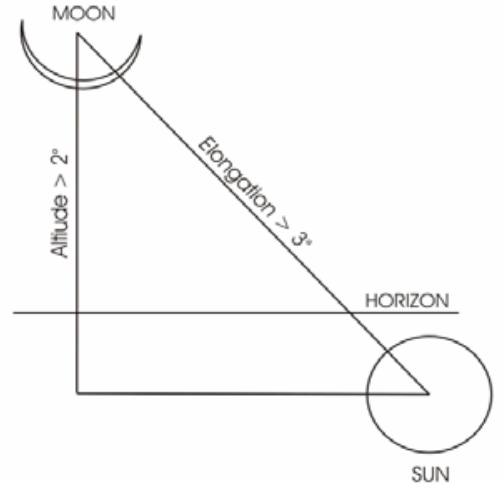

Figure 1. Geometrical parameters of Imkanur rukyah criteria used in Malaysia

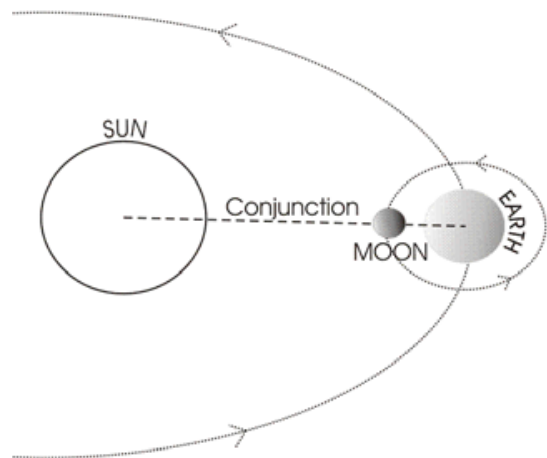

Figure 2. Conjunction Occurrence

The geometric criteria (the altitude and elongation) can depict the relative position of the sun and the moon clearly. For example, if the altitude indicates a negative value, this means that the moon is already below the horizon during sunset and vice versa. While for the elongation, it is able to illustrate a significant arc distance between the moon and the sun. According to Abdurrahman (2014), for the new moon to be successfully perceived by the observer, it must be brighter than the sky background. Therefore, any set of Imkanur rukyah criteria shall contain at least two parameters; a parameter that illustrates the brightness of moon crescent, and the other parameter to represent the brightness of the sky. Hence, the combination of altitude and elongation can be used in predicting the new moon visibility accurately.

In general, for the moon's age criterion, the older the age of the moon, the larger the size of the crescent moon would be. However, the moon's age could not be used as an indicator to visualise the position of the moon in the sky during sunset. Its position varies every month, depending on the position and the movement in its orbit during the conjunction occurrence.

According to Schaefer (1996), the sole use of the moon's age criterion results in a poor prognosis since it does not take into account the brightness of the sky and the crescent moon lighting. It also does not take into account the speed of motion of the moon in its orbit around the earth or even the angle of the moon's declination. 


\section{METHODOLOGY}

In this study, the essential information needed include the position of the moon and the sun, the time of conjunction occurrence, and also the sunset and the moonset time. Figure 3 below shows the concept of determining Hijri dates based on the above information on the $29^{\text {th }}$ day of the Hijri month.

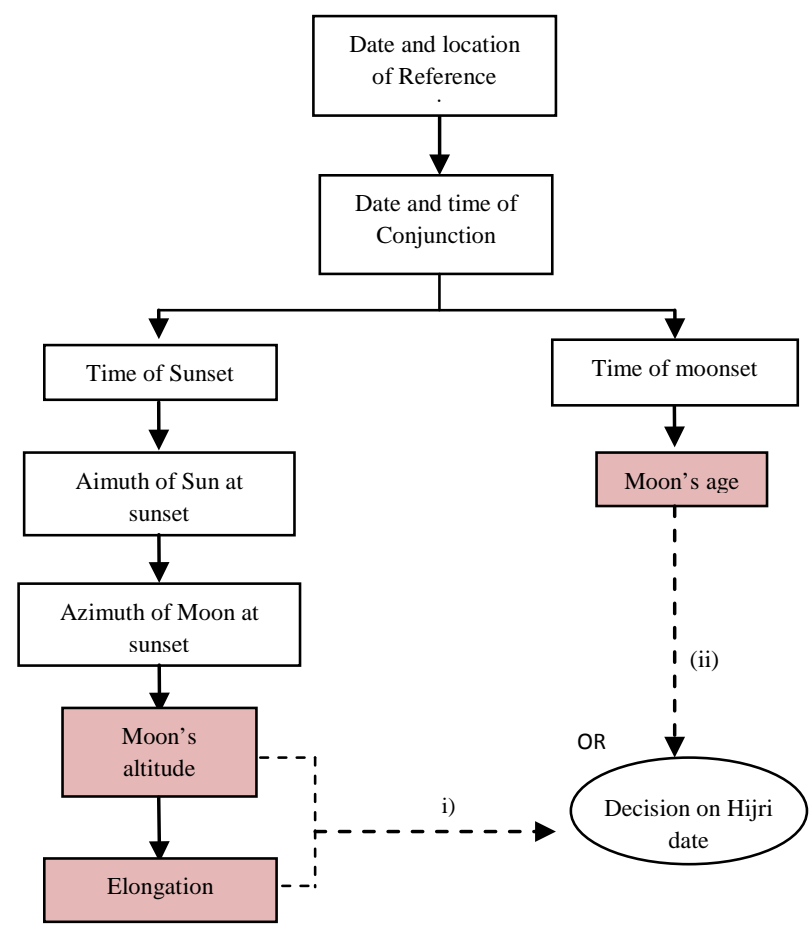

Figure 3. The concept of Hijrah date determination based on Imkanur rukyah criteria

Based on the date of the conjunction occurrence, the sunset time is calculated to determine the azimuth of the sun, the azimuth of the moon and the altitude of the moon. The elongation between the sun and the moon at sunset is then calculated by the following equation.

$$
\operatorname{kos} S_{k}=\operatorname{kos}\left(h_{k}+S D\right) \cdot \operatorname{kos} \Delta A
$$

where,

$\mathrm{S}_{\mathrm{k}}$ : elongation between the sun and the moon

$\mathrm{h}_{\mathrm{k}}$ : apparent altitude of the moon

$\mathrm{SD}$ : semi-diameter of the sun

$\Delta \mathrm{A}$ : relative azimuth between the sun and the moon

On the other hand, the age of the moon is calculated based on the time interval between the moonset and the conjunction.

moon's age $=$ time of moonset - time of conjunction (2)

The algorithm used to calculate the position of the sun and the moon is based on Meeus (1998), by using the theoretical periodic terms of VSOP87 for the sun, and ELP2000-82b ephemeris models for the moon.

\subsection{Scope}

The analyses made were based on the calculation data from 1996 to 2015, given that the full adoption of Imkanur rukyah criteria started in 1996. The information of the sun and the moon data were calculated based on the location of Tanjung Chinchin, Langkawi (6 $6^{\circ} 26^{\prime} 10^{\prime \prime}$ North, $99^{\circ} 38^{\prime} 30^{\prime \prime}$ East); the most western official reference station in determining the date of the Hijri for Malaysia (Figure 4).

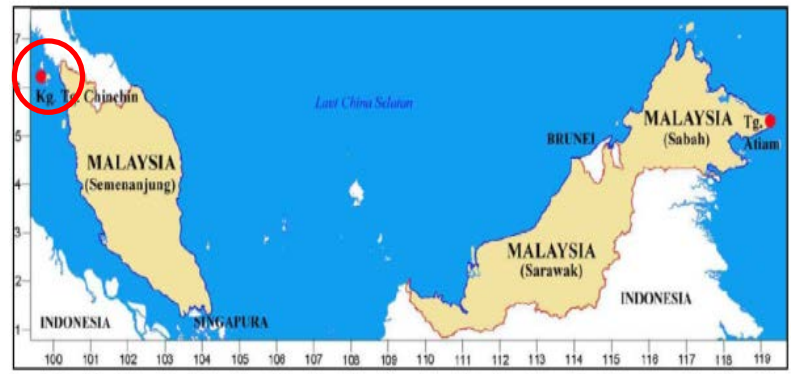

Figure 4. Official reference station in determining the Hijri date for Malaysia (Source: JAKIM, 2011)

From the astronomical perspective, the moon will descend later for the area on the west, which causes the moon's age to be older with higher altitude. Therefore, the probability of the moon to be visible will be much higher.

\section{RESULTS AND ANALYSIS}

The comparisons between the moon's age criteria and the geometric criteria were made for each month from 1996 to 2015, to determine whether there is any discrepancy between them. Based on the analysis, there are 22 disputes found within the specified time range (Table 1), under two conditions, either:

(i) When the age of the moon is more than 8 hours but the geometrical criteria is found to be low than the Imkanur rukyah limit, or

(ii) When the geometric position of the moon and the sun is still higher (above the limit) but then, the moon's age is still below 8 hours.

The first case depicts that, based on the age of the moon, the new moon can be seen. However, looking at the geometric positions of the moon and the sun, it shows that it was very difficult to view the tiny moon crescent because it fell below the minimum visibility condition. For the second case, despite the depiction that the moon was still high in the sky during sunset, the moon's age did not reach the minimum 8-hour condition. As explained previously, this may not be critical if the new moon can be successfully observed. However, if the new moon could not be observed and the reckoning method is decisive, then the discrepancy between these two criteria may pose a problem. 
Table 1. The disputes between the geometric criteria and moon's age.

\begin{tabular}{|c|c|c|c|c|c|}
\hline \multirow[t]{2}{*}{ No } & \multirow[t]{2}{*}{ AD Date } & \multirow[t]{2}{*}{ Hijri Date } & \multicolumn{2}{|c|}{ The Geometric Criteria } & \multirow{2}{*}{$\begin{array}{c}\text { The Moon's } \\
\text { Age } \\
\text { Criterion }\end{array}$} \\
\hline & & & $\begin{array}{l}\text { Altitude of the } \\
\text { Moon at Sunset }\end{array}$ & $\begin{array}{c}\text { Elongation } \\
\text { between the } \\
\text { Moon and the } \\
\text { Sun }\end{array}$ & \\
\hline 1 & 11-11-1996 & 29 Jak 1417 & $+02^{\circ} 52^{\prime} 28.4^{\prime \prime}$ & $3^{\circ} 32^{\prime} 24.9^{\prime \prime}$ & $6 \mathrm{~h} 59 \mathrm{~m}$ \\
\hline 2 & 09-01-1997 & 29 Syb 1417 & $+02^{\circ} 04^{\prime} 29.2^{\prime \prime}$ & $5^{\circ} 13^{\prime} 03.1^{\prime \prime}$ & 7h $08 \mathrm{~m}$ \\
\hline 3 & 19-11-1998 & 29 Rej 1419 & $+02^{\circ} 46^{\prime} 20.3^{\prime \prime}$ & $4^{\circ} 35^{\prime} 58.7^{\prime \prime}$ & $6 \mathrm{~h} 49 \mathrm{~m}$ \\
\hline 4 & 16-04-1999 & 29 Zhj 1419 & $+03^{\circ} 24^{\prime} 01.2^{\prime \prime}$ & $4^{\circ} 55^{\prime} 04.8^{\prime \prime}$ & $7 \mathrm{~h} 25 \mathrm{~m}$ \\
\hline 5 & 08-11-1999 & 29 Rej 1420 & $+03^{\circ} 13^{\prime} 07.0^{\prime \prime}$ & $4^{\circ} 32^{\prime} 24.0^{\prime \prime}$ & $7 \mathrm{~h} 25 \mathrm{~m}$ \\
\hline 6 & 06-03-2000 & 29 Zkh 1420 & $+02^{\circ} 17^{\prime} 59.0^{\prime \prime}$ & $3^{\circ} 32^{\prime} 13.3^{\prime \prime}$ & $6 \mathrm{~h} \mathrm{29m}$ \\
\hline 7 & 04-05-2000 & 29 Muh 1421 & $+03^{\circ} 03^{\prime} 56.3^{\prime \prime}$ & $4^{\circ} 57^{\prime} 22.3^{\prime \prime}$ & 7h 33m \\
\hline 8 & $29-07-2003$ & 29 Jaw 1424 & $+02^{\circ} 13^{\prime} 16.1^{\prime \prime}$ & $4^{\circ} 12^{\prime} 03.7^{\prime \prime}$ & 5h 01m \\
\hline 9 & $14-10-2004$ & 29 Syb 1425 & $+02^{\circ} 23^{\prime} 08.8^{\prime \prime}$ & $2^{\circ} 52^{\prime} 49.9^{\prime \prime}$ & $8 \mathrm{~h} 32 \mathrm{~m}$ \\
\hline 10 & 02-11-2005 & 29 Ram 1426 & $+01^{\circ} 29^{\prime} 42.8^{\prime \prime}$ & $4^{\circ} 46^{\prime} 05.1^{\prime \prime}$ & $9 \mathrm{~h} 47 \mathrm{~m}$ \\
\hline 11 & $25-07-2006$ & 29 Jak 1427 & $+02^{\circ} 48^{\prime} 02.5^{\prime \prime}$ & $3^{\circ} 47^{\prime} 00.6^{\prime \prime}$ & $7 \mathrm{~h} 25 \mathrm{~m}$ \\
\hline 12 & 19-01-2007 & 29 Zhj 1427 & $+02^{\circ} 31^{\prime} 46.1^{\prime \prime}$ & $4^{\circ} 03^{\prime} 56.2^{\prime \prime}$ & 7h 40m \\
\hline 13 & $10-11-2007$ & 29 Syw 1428 & $+01^{\circ} 20^{\prime} 50.9^{\prime \prime}$ & $6^{\circ} 45^{\prime} 51.5^{\prime \prime}$ & 12h 07m \\
\hline 14 & $29-10-2008$ & 29 Syw 1429 & $+01^{\circ} 05^{\prime} 21.3^{\prime \prime}$ & 60 59' 31.9" & $11 \mathrm{~h} 56 \mathrm{~m}$ \\
\hline 15 & 25-04-2009 & 29 Rak 1430 & $+01^{\circ} 26^{\prime} 32.4^{\prime \prime}$ & 6001' 20.1" & $8 \mathrm{~h} 16 \mathrm{~m}$ \\
\hline 16 & $14-02-2010$ & 29 Saf 1431 & $+01^{\circ} 20^{\prime} 02.0^{\prime \prime}$ & $4^{\circ} 17^{\prime} 14.0^{\prime \prime}$ & 8h 50m \\
\hline 17 & $10-08-2010$ & 29 Syb 1431 & + $01^{\circ} 16^{\prime} 44.4^{\prime \prime}$ & $5^{\circ} 22^{\prime} 10.3^{\prime \prime}$ & 8h 38m \\
\hline 18 & 03-02-2011 & 29 Saf 1432 & $+01^{\circ} 41^{\prime} 55.0^{\prime \prime}$ & $4^{\circ} 44^{\prime} 11.7^{\prime \prime}$ & $9 \mathrm{~h} 10 \mathrm{~m}$ \\
\hline 19 & 29-08-2011 & 29 Ram 1432 & $+00^{\circ} 06^{\prime} 50.0^{\prime \prime}$ & $6^{\circ} 40^{\prime} 25.7^{\prime \prime}$ & $8 \mathrm{~h} 29 \mathrm{~m}$ \\
\hline 20 & 16-09-2012 & 29 Syw 1433 & $+00^{\circ} 24^{\prime} 22.8^{\prime \prime}$ & $6^{\circ} 18^{\prime} 05.0^{\prime \prime}$ & 9h $15 \mathrm{~m}$ \\
\hline 21 & 18-05-2015 & 29 Rej 1436 & $+02^{\circ} 34^{\prime} 17.8^{\prime \prime}$ & $4^{\circ} 26^{\prime} 18.0^{\prime \prime}$ & 7h 31m \\
\hline 22 & $16-07-2015$ & 29 Ram 1436 & $+01^{\circ} 40^{\prime} 29.9^{\prime \prime}$ & $6^{\circ} 04^{\prime} 36.5^{\prime \prime}$ & 10h 27m \\
\hline
\end{tabular}

*Muh-Muharram, Saf-Safar, Raw-Rabiulawal, Rak-Rabiulakhir, Jaw-Jamadilawal, Jak-Jamadilakhir, Rej-Rejab, Syb-Syaaban, Ram-Ramadan, Syw-Syawal, Zkh-Zulkaedah, Zhj-Zulhijjah. 
Table 2. The decided date for the beginning of the month of Ramadan, Syawal and Zulhijjah according to PMBRR

\begin{tabular}{|c|c|c|c|c|c|}
\hline 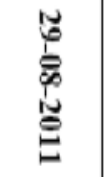 & 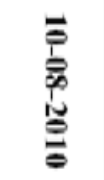 & 裳 & 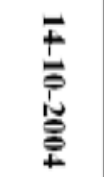 & 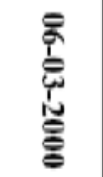 & $\begin{array}{l}\text { 当 } \\
\text { 或 }\end{array}$ \\
\hline 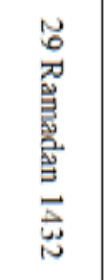 & 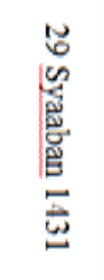 & 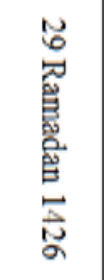 & 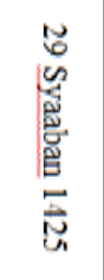 & 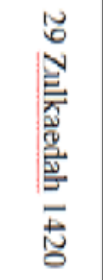 & 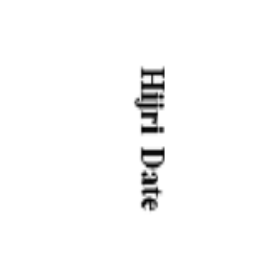 \\
\hline 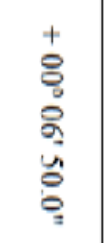 & 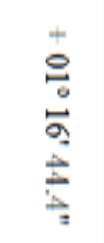 & $\begin{array}{l}+ \\
\stackrel{0}{O} \\
0 \\
\stackrel{0}{0} \\
\hat{N} \\
\infty \\
\infty\end{array}$ & 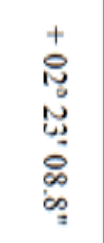 & 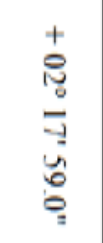 & 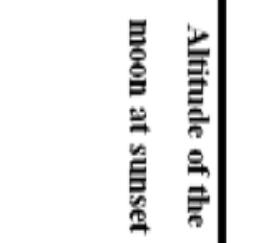 \\
\hline 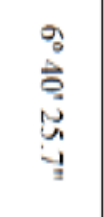 & 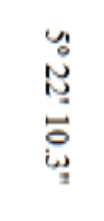 & 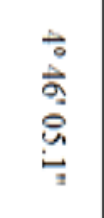 & 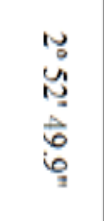 & 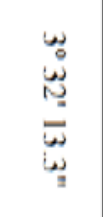 & 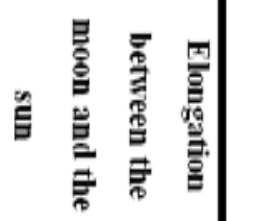 \\
\hline 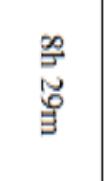 & 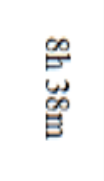 & $\begin{array}{l}\text { 음 } \\
\text { 총 }\end{array}$ & 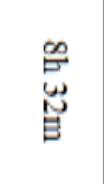 & $\begin{array}{l}\text { קे } \\
\tilde{0} \\
\underline{0}\end{array}$ & 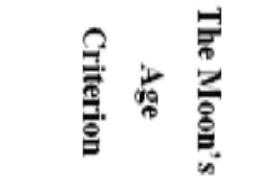 \\
\hline 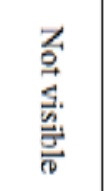 & 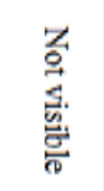 & 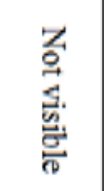 & 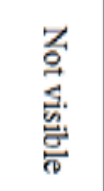 & 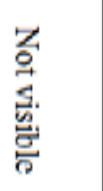 & 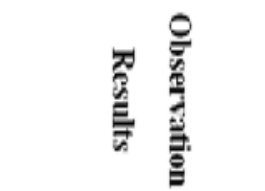 \\
\hline 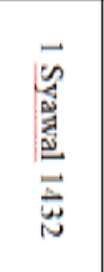 & 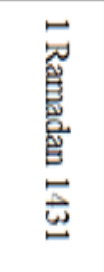 & 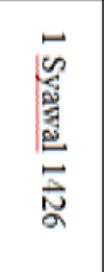 & 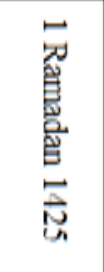 & 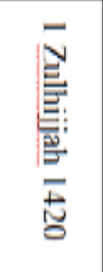 & 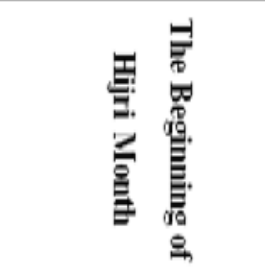 \\
\hline 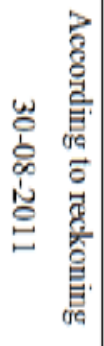 & 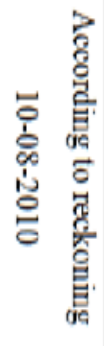 & 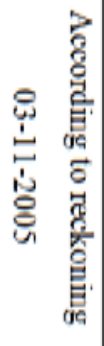 & 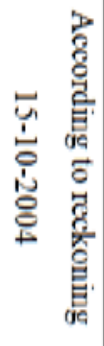 & 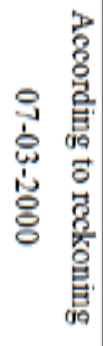 & 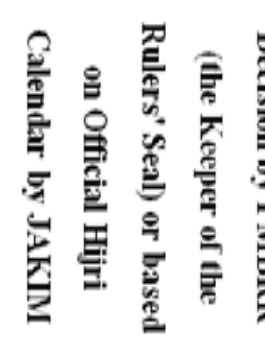 \\
\hline
\end{tabular}


4.1 Determination Date for Ramadan, Syawal and Zulhijjah

Table 2 focused in determining the start of Ramadan, Syawal and Zulhijjah for the particular dates stated in Table 1. The decisions for the month of Ramadan and Syawal are based on the official results of the Keeper of the Rulers' Seal (PMBRR) at http://www.majlisraja-raja.gov.my. While the decided date for the month of Zulhijjah is based on the official Hijri calendar provided by Malaysian Islamic Development Department (JAKIM) at http://www.islam.gov.my.

For the determination of the date of $1^{\text {st }}$ Zulhijjah 1420, it shows that the age has not surpassed the minimum requirement of 8 hours, nevertheless the geometric positions of the moon and the sun met the conditions. Hence, it is decided that the moon as visible. As for the determination of $1^{\text {st }}$ Ramadan 1425, it shows that the elongation between the moon and the sun is less than the minimum requirement $3^{\circ}$, and for $1^{\text {st }}$ Syawal $1426,1^{\text {st }}$ Ramadan 1431 and $1^{\text {st }}$ Syawal 1432, the altitude of the moon was very low and close to the sun. This causes the probability of the moon to be seen is small due to the brightness of the background of the sky at that time. However, since the age of the moon already reached 8 hours, then it is decided as can be seen. Following this, it was decided that the next day as the beginning of the subsequent Hijri Month.

\subsection{Relative Comparison of the Moon's Age Criterion and Geometric Criteria}

For this section, relative comparisons were made by focusing on the value of altitude of $2^{\circ}$, the elongation of $3^{\circ}$ and the moon's age of 8 hours only. Table 3 shows the comparison between the geometric criteria against the moon's age by focusing on the altitude about $2^{\circ}$, Table 4 shows the comparison by focusing on the elongation of $3^{\circ}$, and Table 5 is a comparison of the altitude and the elongation against the moon's age of 8 hours.

Table 3. The moon's age against altitude $2^{\circ}$

\begin{tabular}{cccc}
\hline AD Date & $\begin{array}{c}\text { Altitude } \\
\mathbf{(}^{\circ} \boldsymbol{~}\end{array}$ & $\begin{array}{c}\text { Elongation } \\
\mathbf{(}^{\circ} \boldsymbol{(}\end{array}$ & $\begin{array}{c}\text { Moon's } \\
\text { Age } \\
\text { (hours) }\end{array}$ \\
\hline $\mathbf{1 6 - 0 6 - 1 9 9 6}$ & 2.4 & 2.9 & 8.53 \\
$\mathbf{1 3 - 0 9 - 1 9 9 6}$ & 2.7 & 4 & 9.06 \\
$\mathbf{1 1 - 1 1 - 1 9 9 6}$ & 2.9 & 3.5 & 7 \\
$\mathbf{0 9 - 0 1 - 1 9 9 7}$ & 2.1 & 5.2 & 7.13 \\
$\mathbf{0 2 - 0 9 - 1 9 9 7}$ & 2.7 & 3.9 & 11.84 \\
$\mathbf{2 2 - 0 8 - 1 9 9 8}$ & 2.4 & 3.1 & 9.72 \\
$\mathbf{1 9 - 1 1 - 1 9 9 8}$ & 2.8 & 4.6 & 6.82 \\
$\mathbf{1 3 - 0 7 - 1 9 9 9}$ & 2.8 & 3.8 & 7.42 \\
$\mathbf{0 6 - 0 3 - 2 0 0 0}$ & 2.3 & 3.5 & 6.49 \\
$\mathbf{2 9 - 0 7 - 2 0 0 3}$ & 2.2 & 4.2 & 5.01 \\
$\mathbf{1 4 - 1 0 - 2 0 0 4}$ & 2.4 & 5.8 & 10.24 \\
$\mathbf{3 1 - 1 2 - 2 0 0 5}$ & 2.6 & 4.4 & 7.52 \\
$\mathbf{2 5 - 0 7 - 2 0 0 6}$ & 2.8 & 4.1 & 9.54 \\
\hline
\end{tabular}

\begin{tabular}{cccc}
\hline $\mathbf{2 1 - 1 1 - 2 0 0 6}$ & 2.5 & 4.1 & 7.66 \\
$\mathbf{1 9 - 0 1 - 2 0 0 7}$ & 2.5 & 7 & 12.97 \\
$\mathbf{1 9 - 0 3 - 2 0 0 7}$ & 2.7 & 4.6 & 12.48 \\
$\mathbf{0 7 - 0 2 - 2 0 0 8}$ & 2.2 & 2.2 & 8 \\
$\mathbf{2 5 - 0 2 - 2 0 0 9}$ & 2.2 & 4.6 & 10.18 \\
$\mathbf{0 7 - 0 8 - 2 0 1 3}$ & 2.1 & 4.8 & 10.8 \\
$\mathbf{0 5 - 1 0 - 2 0 1 3}$ & 2.1 & 6.9 & 13.17 \\
$\mathbf{2 7 - 0 7 - 2 0 1 4}$ & 2.1 & 7.5 & 13.99 \\
$\mathbf{1 8 - 0 5 - 2 0 1 5}$ & 2.6 & 5.8 & 8.35 \\
\hline
\end{tabular}

Table 4. The moon's Age against elongation $3^{\circ}$

\begin{tabular}{cccc}
\hline AD Date & $\begin{array}{c}\text { Altitude } \\
\mathbf{(}^{\circ}\end{array}$ & $\begin{array}{c}\text { Elongation } \\
\mathbf{(}^{\circ} \mathbf{)}\end{array}$ & $\begin{array}{c}\text { Moon's } \\
\text { Age } \\
\text { (hours) }\end{array}$ \\
\hline $\mathbf{1 1 - 1 1 - 1 9 9 6}$ & 2.9 & 3.5 & 7 \\
$\mathbf{0 2 - 0 9 - 1 9 9 7}$ & 2.7 & 3.9 & 11.84 \\
$\mathbf{3 1 - 1 0 - 1 9 9 7}$ & 0.4 & 3.4 & 1.09 \\
$\mathbf{2 8 - 0 1 - 1 9 9 8}$ & 0.8 & 3.1 & 5.58 \\
$\mathbf{2 8 - 0 3 - 1 9 9 8}$ & 3.7 & 3.9 & 8.6 \\
$\mathbf{2 2 - 0 8 - 1 9 9 8}$ & 2.4 & 3.1 & 9.72 \\
$\mathbf{2 0 - 1 0 - 1 9 9 8}$ & 0.6 & 3.6 & 1.02 \\
$\mathbf{0 6 - 0 3 - 2 0 0 0}$ & 2.3 & 3.5 & 6.49 \\
$\mathbf{3 1 - 0 7 - 2 0 0 0}$ & 3.8 & 3.9 & 9.57 \\
$\mathbf{2 3 - 0 2 - 2 0 0 1}$ & 0.7 & 3.6 & 3.31 \\
$\mathbf{2 3 - 0 5 - 2 0 0 1}$ & 3.1 & 3.8 & 9.03 \\
$\mathbf{2 5 - 0 7 - 2 0 0 6}$ & 2.8 & 3.8 & 7.42 \\
$\mathbf{2 2 - 0 7 - 2 0 0 9}$ & 3.1 & 3.8 & 9.38 \\
$\mathbf{2 1 - 0 5 - 2 0 1 2}$ & 3.6 & 3.6 & 12.05 \\
$\mathbf{1 0 - 0 5 - 2 0 1 3}$ & 3.4 & 3.4 & 11.31 \\
$\mathbf{1 3 - 1 0 - 2 0 1 5}$ & 3.7 & 3.7 & 11.34 \\
$\mathbf{0 9 - 0 3 - 2 0 1 6}$ & 3.6 & 3.8 & 9.94 \\
\hline & & & \\
\hline
\end{tabular}

Table 5. The altitude and the elongation against the moon's age of 8 hours

\begin{tabular}{cccc}
\hline AD Date & $\begin{array}{c}\text { Altitude } \\
\left({ }^{\circ}\right)\end{array}$ & $\begin{array}{c}\text { Elongation } \\
\left.\mathbf{(}^{\circ}\right)\end{array}$ & $\begin{array}{c}\text { Moon's } \\
\text { Age } \\
\text { (hours) }\end{array}$ \\
\hline $\mathbf{2 8 - 0 3 - 1 9 9 8}$ & 3.7 & 3.9 & 8.6 \\
$\mathbf{0 7 - 0 9 - 2 0 0 2}$ & 4.8 & 5.2 & 8.64 \\
$\mathbf{2 6 - 0 9 - 2 0 0 3}$ & 3.9 & 4 & 8.43 \\
$\mathbf{1 4 - 1 0 - 2 0 0 4}$ & 2.4 & 2.9 & 8.53 \\
$\mathbf{0 5 - 0 8 - 2 0 0 5}$ & 3.5 & 4.3 & 8.88 \\
$\mathbf{3 1 - 1 2 - 2 0 0 5}$ & 2.6 & 5.8 & 8.35 \\
$\mathbf{1 5 - 0 6 - 2 0 0 7}$ & 3.3 & 5.4 & 8.7 \\
$\mathbf{0 7 - 0 2 - 2 0 0 8}$ & 2.2 & 2.2 & 8 \\
$\mathbf{2 5 - 0 4 - 2 0 0 9}$ & 1.4 & 6 & 8.26 \\
$\mathbf{1 4 - 0 2 - 2 0 1 0}$ & 1.3 & 4.3 & 8.84 \\
\hline
\end{tabular}




\begin{tabular}{cccc}
\hline $\mathbf{1 0 - 0 8 - 2 0 1 0}$ & 1.3 & 5.4 & 8.63 \\
$\mathbf{2 9 - 0 8 - 2 0 1 1}$ & 0.1 & 6.7 & 8.49 \\
$\mathbf{0 5 - 0 6 - 2 0 1 6}$ & 3 & 5.9 & 8.84 \\
\hline
\end{tabular}

From Table 3, when the altitude ranged from $2.1^{\circ}$ to $2.9^{\circ}$, the moon's age changed within 5 hours to 14 hours range. While from Table 4, for the elongation within $3.1^{\circ}$ to $3.9^{\circ}$ range, the age is found to vary between 1 to 12 hours. And as for the comparison based on the 8 hours moon's age (Table 5), it shows that the altitude of the moon can be as low as $0.1^{\circ}$, while the elongation can reach $2.2^{\circ}$. These situations suggest that the altitude criteria $2^{\circ}$ and elongation criteria $3^{\circ}$ are not always consistent to the minimum age of 8 hours. Hence, the moon's age and the geometric criteria are not suitable to be as an alternative to each other.

\section{CONCLUSIONS AND RECOMMENDATIONS}

It is evident that the age of the moon is not always consistent with the geometric positions of the moon and the sun. The position of the moon at sunset depends on several factors, especially the position of the moon in its orbit and the relative movement of the moon and the sun after the conjunction.

In general, the age of the moon will increase gradually, and at the same time, the moon's altitude will slowly increase and decrease, following the movement of the moon in the horizon system. For the elongation method, it is assumed that the older the moon's age, the further the moon would distance itself from the sun and the arc would be bigger. However, this situation is not consistent every month throughout the year.

In addition, when the moon is at perigee, which is the closest point in the orbit of the moon, the moon will quickly distance itself from the sun and a large elongation angle immediately can be reached. Similarly, when the moon is close to the highest or the lowest ecliptic latitude, (i.e $+5.5^{\circ}$ and $-5.5^{\circ}$ ), the elongation angle will also increase.

As mentioned before, for the new moon to be successfully perceived by the observer, it must be brighter than the sky background. This means that any set of Imkanur rukyah criteria should contain at least two parameters; a parameter for the brightness of moon crescent, and the other parameter for the brightness of the sky. According to Odeh (2006), the appearance of the new moon cannot be predicted by using one parameter only. At least two parameters should be used together to create an accurate prediction. As a conclusion, it is better if the existing Imkanur rukyah criteria only consider the geometric criteria, without the moon's age criterion as an alternative.

\section{REFERENCES}

Al-Qur'an Tafsir Darul Iman (2011). Pustaka Darul Iman, Kuala Lumpur.

Abdurrahman Ozlem (2014). A Simplified Crescent Visibility Criterion. Retrieved on November $29^{\text {th }}$, 2014, from http://www.icoproject.org/.
Azhari, M. (2012). Penetapan Awal bulan Hijriah: Ramadan, Syawal dan Zulhijjah 1433 H/ 2012 M. NRE Executive Discourse. 18 Mei 2012.

Bentchikou, A., Rasiwala, M. dan Patel, A. (2011). On The Visibility of The Earliest Crescent Moon: An Islamic Calendar for Makkah. Selenology Today. 21, 39-58.

JAKIM (2011). Kenyataan Media Ketua Pengarah Jabatan Kemajuan Islam Malaysia Berkenaan Isu Penentuan Awal Bulan Syawal $1432 H$. Retrieved on January $5^{\text {th }}$, 2015, from http://www.islam.gov.my/

Meeus, J (1998). Astronomical Algorithms. (2 ${ }^{\text {nd }}$ ed.). Richmond, Virginia: Willmann-Bell.

Odeh, M.S. (2006). New Criterion for Lunar Crescent Visibility. Experimental Astronomy. 18, 39-64. Springer, 2006.

Samad Hj. Abu, Azhari Mohamed dan Norlizam Rejab (2003). Kaedah Penentuan Awal Ramadhan, Syawal dan Zulhijjah di Malaysia. Muzakarah Falak (JAKIM). 30 Jun 2 Julai 2003. Corus Paradise Resort, Port Dickson, Negeri Sembilan.

Schaefer, B. E. (1996). Lunar Crescent Visibility. Quarterly Journal of the Royal Astronomical Society. 37, 759-768.

S. Sakirman (2012). Analisis Fotometri Kontras Visibilitas Hilal Terhadap Cahaya Syafaq. Tesis Pascasarjana. Institut Agama Islam Negeri (IAIN). Walisongo Semarang. 